This is the final peer-reviewed accepted manuscript of:

Akerman, A., Naghavi, A., \& Seim, A. (2016). Oligarchies and development in a global economy: a tale of two elites. Economic Inquiry, 54(1), 229-246.

The final published version is available online at:

https://doi.org/10.1111/ecin.12284

Rights / License:

The terms and conditions for the reuse of this version of the manuscript are specified in the publishing policy. For all terms of use and more information see the publisher's website.

This item was downloaded from IRIS Università di Bologna (https://cris.unibo.it/)

When citing, please refer to the published version. 


\title{
Oligarchies and Development in a Global Economy: A Tale of Two Elites*
}

\author{
Anders Akerman ${ }^{\dagger} \quad$ Alireza Naghavi ${ }^{\ddagger} \quad$ Anna Seim ${ }^{\S}$
}

July 2015

\begin{abstract}
This paper studies how comparative advantage and the political elites' endowments shape long-run performance in economies with imperfect political institutions. The trade regime interacts with industrial policy and regulations on capital mobility in governing capital accumulation. In a capital-scarce economy, capitalist oligarchs striving for Import Substitution Industrialization (ISI) initially shelter the economy from trade, while promoting industrial policies that promote TFP-growth in the manufacturing sector. This gradually shifts the comparative advantage towards manufacturing and renders the economy attractive to foreign investors. Allowing for trade and foreign capital inflows are thus complementary policies that spur growth in the capital oligarchy. By contrast, landed oligarchs in a capital-scarce economy favor openness to trade at an early stage of development, neglect industrial policies and block foreign capital to maximize extractable rents. The policy mix causes the economy to stagnate. Consistent with the experiences of South Korea and Argentina in the postwar era, the model predicts that the success of ISI-policies depends crucially on the conditions governing the incentives for capital accumulation.
\end{abstract}

JEL-Classification: F10; F20; P40; P50; 010; O24.

Keywords: political institutions; development; economic institutions; trade; comparative advantage; capital mobility; capital accumulation.

${ }^{*}$ We are indebted to Marianna Belloc, Matteo Cervellati, I-Hui Cheng, Rikard Forslid, Volker Grossman, NilsPetter Lagerlöf, Heléne Lundqvist, David Mayer-Foulkes and Peter Neary for very helpful comments. We would also like to thank seminar participants at Uppsala University, conference participants at the 26th annual congress of the European Economic Association in Oslo 2011, the Annual Meeting of Swedish Economists 2011, XVI conference on Dynamics, Economic Growth and International Trade in St. Petersburg 2011, the Italian Trade Study Group in Rome 2012, and the Public Economic Theory annual conference in Taipei 2012. Any remaining errors are our own. Financial support from the Jan Wallander and Tom Hedelius Research Foundation and the Swedish Research Council, Stiftelsen Söderströms Donationsfond (Project number FOA09H-355), and from MIUR, through the PRIN project "Institutions, Social Dynamics, and Economic Development", is gratefully acknowledged by Anders Akerman, Anna Seim and Alireza Naghavi, respectively.

${ }^{\dagger}$ Department of Economics, Stockholm University, SE-106 91 Stockholm, Sweden. Phone: + 468162163 . E-mail: anders.akerman@ne.su.se.

${ }^{\ddagger}$ University of Bologna, Department of Economics, Piazza Scaravilli 2, Bologna 40126, Italy. Phone: + 39051209 8873. Email: alireza.naghavi@unibo.it.

${ }^{\S}$ Department of Economics, Stockholm University, SE-106 91 Stockholm, Sweden. Phone: + 468163865 . E-mail: anna.seim@ne.su.se. 


\section{Introduction}

Data from the post World-War II era of globalization reveal a striking variation in the growth performance of non-democratic countries: they tend to either excel or fall behind. At the lower end of the spectrum are some of the world's poorest performing economies, and at the upper end the miraculous East Asian Tiger Economies, who have doubled their income in a decade or less since the beginning of the 1960s. Openness to trade appears to have been conducive to growth in some non-democracies, but not in others. How can we explain these differences in performance?

This research highlights an empirical feature that has been somewhat overlooked in the literature: the fact that the endowments of the political elites differ across countries. We build a specific-factor trade model of an oligarchy, where the nature of the ruling political elites and the comparative advantage determine the economy's long-term performance 1 The paper argues that the interaction of the trade regime with industrial policies and with international capital mobility is crucial for growth and development. If the political elites are landowners in a capital-scarce economy, openness to trade creates an environment of institutional neglect and stagnation. However, if the political elites are instead capitalists, they gradually shift the comparative advantage towards manufacturing by promoting sound industrial policies, which eventually provides an incentive to open up to trade and allow for foreign capital inflows. We also add to the existing literature by stressing that the complementarity of policies on trade and capital mobility is crucial for the economic success of oligarchies and show that such complementarities arise if the ruling elites are capitalists ${ }^{2}$

A growing strand of literature emphasizes how political and economic institutions shape long-run performance and helps us understand some of the reasons non-democracies differ, see for instance Acemoglu, Johnson and Robinson (2005a) and Acemoglu and Robinson (2006) for overviews $3^{3}$ The relationship between openness and institutions has become subject to intensive research only in recent years and the empirical results are mixed. Free trade can either lead to stronger institutions as in Ades and Di Tella (1999), Acemoglu, Johnson and Robinson (2005b), Rodrik, Subramanian and Trebbi (2004) and Rigobon and Rodrik (2005), or to institutional deterioration as in Treisman

\footnotetext{
${ }^{1}$ For seminal contributions to the class of specific-factor models see Jones (1971), Samuelson (1971), Mussa (1974) and Neary (1978).

${ }^{2}$ The notion that trade in goods and capital movements interact with each other, and can be either complements or substitutes, is the subject of a large literature comprising Markusen (1983), Jones and Neary (1984), Markusen and Svensson (1985), Wong (1986), Jones (1989), and Neary (1995).

3 Within this literature, more specific forms of imperfect political institutions include expropriation (SeguraCayuela, 2006; Stefanadis, 2010, Albornoz, Galiani and Heymann, 2012) and inequality in land ownership (Galor, Moav and Vollrath, 2009; Falkinger and Grossman, 2013).
} 
(2003) and Tavares (2007). As argued by Stefanadis (2010), the empirical literature has been ahead of theory in this area and more theoretical work is needed to deepen our understanding of the interaction between globalization and the quality of institutions.

While proponents of trade argue that economic integration is conducive to stronger institutions, a series of recent papers point out that this is not always the case. Johnson, Ostry, and Subramanian (2007) suggest that if returns from trade fall into the hands of a small elite, the concentration of power that may follow can worsen institutions. Bardhan (2010) confirms that the trade expansion in natural resource intensive products has strengthened the political power of large exporters who subsequently have raised barriers to entry and promoted elite institutions. Levchenko (2013) adds that trade improves the institutional quality if it reduces the rents from dysfunctional institutions, but brings institutional deterioration in the opposite case. Galiani and Torrens (2014) introduce trade policy as a political cleavage between different types of elites. In the presence of intra-elite conflict, elite groups bargain to control the economy and confront popular revolt by shifting power to the group whose preferred trade policy is in line with workers' demands. Other theoretical papers have demonstrated the negative effect of autocracies opening to trade on domestic economic institutions such as investment in schooling (Falkinger and Grossman, 2005), the investment climate (Do and Levchenko, 2009), property rights (Stefanadis, 2010), and technology adoption (Cervellati, Naghavi and Toubal, 2013).

We contribute to the aforementioned literature by building a theory showing that the effects of trade on economic institutions are contingent on the nature of the political elites. We model an oligarchy, consisting of an agricultural sector and a manufacturing sector. The political elites hold either land or capital and we shall henceforth refer to these economies as land and capital oligarchies, respectively. Capital accumulation derives from capitalists leaving bequests to their children, and the price of bequests crucially determines the saving environment of the economy $\left.\right|^{4}$ The economic institution that we focus on is an industrial policy that encourages growth in the manufacturing sector. We also introduce capital market liberalization as an additional policy instrument that interacts with the trade regime in determining economic performance. The rulers' policy space thus comprises the following elements: (i) allowing for international trade in goods; (ii) strengthening economic institutions that promote manufacturing TFP; and (iii) allowing for the inflow of foreign capital.

\footnotetext{
${ }^{4}$ We thank a referee for suggesting that bequest costs may vary across countries. Bequests could for example be more costly in an unstable political environment due to the risk of future expropriation.
} 
The construct allows us to model strategies of Import Substitution Industrialization (ISI): by prohibiting trade, the oligarchs can encourage the domestic industrial sector and protect it against foreign competition. We consider a setting where each economy is characterized by an initial comparative disadvantage in manufacturing and study the optimal regimes chosen in three types of oligarchies: a benchmark capital oligarchy with inexpensive bequests, a land oligarchy and a capital oligarchy with expensive bequests. We show that the different types of oligarchs choose trade regime based on the comparative (dis)advantage of the factor that they hold and subsequently choose different industrial policies. In addition, the endowments of the political elites govern whether openness to trade and foreign capital inflows are complementary policies.

The results suggest that the benchmark capitalist oligarchy initially shelters the economy from global markets while promoting industrial policies that encourage the development of the manufacturing sector. By creating an environment conducive to capital accumulation and growth, a comparative advantage in manufacturing is eventually achieved and the oligarchs open up to trade once the domestic economy has grown sufficiently strong. The strong industrial policies further succeed in attracting productive, foreign capital, which further spurs growth. The benefits of allowing for foreign capital inflows are realized only once the economy is open to trade so that openness to trade and foreign capital imports are complementary policies. This finding is consistent with Rodrik (1994), who stresses that an important factor behind the outstanding performances of South Korea and Taiwan was indeed governments' abilities to raise the returns to private investments, thereby increasing the demand for imported capital goods. Moreover, the entrepreneurial elites in these miracle economies promoted large-scale capital inflows only after opening up to trade in the 1970 's. 5

Landed oligarchs prefer to open up to trade at an early stage of development, which impedes growth by creating an environment where economic institutions are neglected. The weak institutions render the economy unattractive to foreign investors and the landed elites opt against the inflow of foreign capital. The landed oligarchy is thus bound for stagnation. The complementarity between openness to trade and the inflow of foreign capital that works as a catalyst for growth in the capital oligarchy, fails to materialize in the land oligarchy. The predictions for this economy are broadly consistent with the development of Argentina in the 19th century, when the political power lay in the hands of landowners and the country primarily traded large volumes of agrarian

\footnotetext{
${ }^{5}$ Source: Statistics on Approved Overseas Chinese and Foreign Investment by Area, the Investment Commission, Ministry of Economic Affairs, Taiwan.
} 
products.

Finally, we consider a capital autocracy where the saving environment is less beneficial than in the benchmark. Allowing the price of bequests to exceed that of current consumption changes the trade-off between consumption and bequests faced by capitalists and creates weaker incentives to invest. This capital autocracy still chooses to pursue an ISI-strategy by prohibiting trade and promoting industrial policies, but capital accumulation is now hampered. The moderate growth of the domestic capital stock delays the comparative-advantage reversal and the economy opens up to trade later than in the benchmark capital oligarchy. In terms of growth, this economy outperforms the land oligarchy, but falls short of its counterpart with inexpensive bequests. This experiment shows that being ruled by capitalists is no guarantee for growth - institutions conducive to capital accumulation must also be in place. The predictions for this example economy are largely consistent with developments in Argentina in the postwar period when politicians, catering to the preferences of industrial elites and workers, implemented ISI policies that were unsuccessful in fostering growth. In the case of Argentina, this led to the coup of 1976 in which the military government backed by the agricultural elite seized power (Brambilla, Galiani, and Porto, 2010).

In sum, our model thus suggests the following: (i) starting out with a comparative advantage in agriculture, capitalist oligarchs will choose an ISI strategy and stay closed to trade while land oligarchs will open immediately; (ii) capitalist oligarchs strengthen economic institutions in an open economy while landed oligarchs neglect them; (iii) trade in goods and capital imports are complementary policies in a capital oligarchy but not in a land oligarchy; (iv) being ruled by industrialists is no panacea for miracle growth - institutions conducive to capital accumulation must also be in place.

The rest of the paper is organized as follows. Section 2 presents the model. Section 3 discusses the equilibrium under different trade regimes. Section 4 introduces international capital mobility. Section 5 presents the political-economy layer of the model and derives analytical results on optimal policies. The results from a numerical simulation of the model are presented in Section 6. A discussion based on historical anecdotal evidence is presented in Section 7. Section 8 concludes.

\section{The Model}

Consider a small, potentially open economy. The economy consists of two sectors denoted $j=A, M$ for agriculture and manufacturing. Each sector produces a sector-specific good that is tradable in 
the world market. There are three groups of households that differ in their initial endowments and supply either land, capital or labor to firms. We assume that each time period, denoted $t$, is one generation so that households and policy makers have one-period lives. Owners of the factors of production have warm-glow preferences and leave bequests ${ }^{6}$

We vary the assumption on the nature of the ruling oligarchs and assume that they are either landowners or capitalists.7 The oligarchs govern economic institutions and make decisions on whether or not to allow for international trade in goods and the inflow of foreign capital.

We first treat regimes as exogenously given and focus on solving the economic model in Sections 2-4. Since we are ultimately interested in how the ruling elites choose policies, we put particular emphasis on the real returns to capital and land under different regimes in these sections. The preferences and optimal choices of the oligarchs are then analysed in Section 5 .

\subsection{Production}

The agricultural and manufacturing sectors differ in terms of technology and the factors employed in production. Labour is the only input used in both technologies and is perfectly mobile across the two sectors so that the labor supply is infinitely elastic.

The agricultural sector uses land $(X)$ and labor $(L)$ to produce the agricultural good. Letting $Y_{A}$ denote the output of the agricultural good:

$$
Y_{A t}=X_{t}^{\alpha} L_{A t}^{1-\alpha}
$$

where $\alpha \in(0,1)$ and $L_{A t}$ denotes the labor employed in the sector.

The manufacturing sector uses capital $(K)$ and labor to produce the manufacturing good:

$$
Y_{M t}=A_{M t} K_{t}^{\alpha} L_{M t}^{1-\alpha}
$$

where $A_{M t}$ denotes total factor productivity in the manufacturing sector and $L_{M t}$ refers to the labor employed in the sector $8 K_{t}=A_{K t} K_{D t}+K_{F t}$ is the total effective capital stock in the economy and comprises domestic and foreign capital, $K_{D t}$ and $K_{F t}$, respectively. We treat $A_{K t}$ as

\footnotetext{
${ }^{6}$ The warm-glow preference structure enables us to characterize the equilibrium in each period. The bequests ensure that there is a dynamic link between periods and that the capital stock is growing over time.

${ }^{7}$ The possibility that autocrats may be heterogeneous and have different objectives is also present in Shen (2007), Paltseva (2008) and Seim and Parente (2013). However, these papers do not take into account that the endowments of the political elites may be country-specific.

${ }^{8}$ We assume labour intensity, $1-\alpha$, to be the same in both sectors. The assumption is made for simplicity and is of minor importance: sectoral differences in terms of labour's share in production are not related to the dynamics of interest in our model.
} 
a parameter for now to derive equilibrium expressions that hold for $K_{F t} \geq 0$, and will return to this issue in Section 4.9

While total factor productivity is assumed to be constant and normalized to one in the agricultural sector, TFP in the manufacturing sector grows at some exogenous rate $\gamma_{t}>0$. However, the evolution of manufacturing TFP is also governed by industrial policy. Specifically, $A_{M t}$ evolves according to:

$$
A_{M t}=\left(1+\pi_{M t} \gamma_{t}\right) A_{M t-1}
$$

where $\pi_{M t} \in[0,1]$ is a policy variable. The construct allows us to think of $\pi_{M t}$ as a broad measure of the quality of economic institutions, capturing the extent to which policy makers seek to promote technological progress. In an environment with strong economic institutions, i.e. where industrial policy is conducive to technology adoption, $\pi_{M t}=1$, so that manufacturing TFP grows at its full potential.

\subsection{Endowments, Preferences and Income}

The population consists of capitalists, indexed $K$, landowners, indexed $X$, and workers, indexed $L$. Letting $N_{K}, N_{X}$ and $L$ denote the measure of each group, the total population at time $t$ is $N_{t}=N_{K t}+N_{X t}+L_{t}$. We assume a stationary population normalized to one, as population growth is of no importance for the dynamics of interest in our setting. Landowners hold one unit of land which they rent to firms in the agricultural sector, while capitalists rent their capital to firms in the manufacturing sector 10

Owners of the factors of production derive utility from consumption and from leaving bequests to the next generation, depending on the nature of their endowment. Since our focus is on a regime where equilibrium outcomes are driven by the preferences of the political elites, we assume for simplicity that workers do not hold any resources, leave no bequests and hence consume their entire income. The utility function of the elites takes the following form:

$$
U\left(C_{t}, B_{h t}\right)=C_{t}^{\mu} B_{h t}^{1-\mu}
$$

\footnotetext{
${ }^{9}$ A key feature of the model is an assumption that domestic capital is less productive than foreign capital and we let the parameter $A_{K t}$ denote the relative productivity of domestic capital. At a later stage, we will model $A_{K t}$ as a function of $K_{F t}$, thereby assuming that the presence of foreign, more productive capital will have positive spillover effects on domestic capital. In equilibrium the presence of such capital will hinge on domestic returns to capital being sufficiently high as well as the ruling oligarchs allowing for such capital inflows.

10 An alternative would be to assume that landed oligarchs own agricultural firms and capitalist oligarchs own manufacturing firms so that they are residual claimants. The main results would obtain also in such a framework.
} 
for $h=K, X$ where $C_{t}=C_{A t}^{\sigma} C_{M t}^{1-\sigma}$ is aggregate consumption, $B_{h t}$ denotes bequests, and the maximization is subject to constraints that are household-specific. Land and capital differ in that land does not depreciate while capital depreciates fully from one generation to another. This means that landowners simply leave their land endowments to their successor while capitalists bequeath a share of their income in terms of an investment good. This makes bequests solely a part of the budget constraint of capital owners, i.e. $\mu=1$ for landowners 11

Let $P_{A t}, P_{M t}$ and $P_{B t}$ denote the prices of agricultural, manufacturing and bequest goods respectively. For simplicity, we assume that savings are made in terms of manufacturing goods, which implies $P_{B t}=\xi P_{M t}$. The parameter $\xi \geq 1$ indicates how costly bequests are relative to current consumption and allows us to study the effects of different saving environments. We treat the manufacturing sector as the numéraire sector and set $P_{M t}$ to unity. $P_{A t}$ therefore denotes the relative price of agricultural goods in terms of manufacturing goods. Define the general price level as the nominal income needed to buy one unit of the optimal basket of consumption and savings, so that the price index facing each group is $P_{h t}=\xi^{(1-\mu)} P_{A t}^{\mu \sigma}$.

Under these assumptions, the indirect utility functions of the elite households are:

$$
V_{h t}=\lambda_{h} \frac{i_{h t} \varkappa_{h t}}{\xi^{(1-\mu)} P_{A t}^{\mu \sigma}}
$$

where $i_{h t}$ denotes returns to each sector-specific factor of production, $\varkappa_{h t}=h_{D t} / N_{h t}$ is the factor endowment of each elite individual, and $\lambda_{h} \equiv(\mu \sigma)^{\mu \sigma}(\mu(1-\sigma))^{\mu(1-\sigma)}(1-\mu)^{(1-\mu)}$ with $\mu=1$ for landowners.

\section{Equilibrium under Different Trade Regimes}

This section solves for the equilibrium prices of goods, factor allocations, returns and output levels in the two sectors under different trade regimes. We start by discussing general equilibrium conditions in Section 3.1, and proceed by discussing the equilibria in closed and open economies in Sections 3.2 and 3.3 , respectively.

\footnotetext{
${ }^{11}$ See Appendix A1 for details of the households' maximization problems.
} 


\subsection{General}

From the profit-maximization problems of firms it follows that returns to capital, land and labor are given by:

$$
\begin{aligned}
i_{K t} & =\frac{\partial Y_{M t}}{\partial K_{t}}=\alpha\left(1+\pi_{M t} \gamma_{t}\right) A_{M t-1} K_{t}^{\alpha-1} L_{M t}^{1-\alpha}, \\
i_{X t} & =P_{A t} \frac{\partial Y_{A t}}{\partial X_{t}}=P_{A t} \alpha X_{t}^{\alpha-1} L_{A t}^{1-\alpha} \\
w_{M t} & =\frac{\partial Y_{M t}}{\partial L_{M t}}=(1-\alpha)\left(1+\pi_{M t} \gamma_{t}\right) A_{M t-1} K_{t}^{\alpha} L_{M t}^{-\alpha} \\
w_{A t} & =P_{A t} \frac{\partial Y_{A t}}{\partial L_{A t}}=P_{A t}(1-\alpha) X_{t}^{\alpha} L_{A t}^{-\alpha}
\end{aligned}
$$

Equation (5) defines returns to effective capital $K_{t}$. Since domestic and foreign capital differ in productivity, returns to each type of capital will differ accordingly. The manufacturing firms' optimal choices of each type of capital input, imply that the returns to domestic and foreign capital, respectively, are given by:

$$
\begin{aligned}
i_{D t} & =\frac{\partial Y_{M t}}{\partial K_{D t}}=A_{K t} i_{K t} \\
i_{F t} & =\frac{\partial Y_{M t}}{\partial K_{F t}}=i_{K t}
\end{aligned}
$$

where $i_{K t}$ is given by (5).

Regardless of the trade regime, under full employment and inelastic labor supply, employment in the two sectors adds up to the total labor supply:

$$
L_{t}=L_{A t}+L_{M t}
$$

Labour can move freely between the two sectors, equalising the wage across sector so that $w_{t}=$ $w_{A t}=w_{M t}$. Equations (7) and (8) imply:

$$
P_{A t}=\left(1+\pi_{M t} \gamma_{t}\right) A_{M t-1}\left(\frac{K_{t}}{X_{t}} \frac{L_{A t}}{L_{M t}}\right)^{\alpha}
$$

\subsection{Closed Economy}

In autarky, prices are endogenously determined in the domestic market. Aggregating the demand functions over the population yields aggregate demand for agricultural goods:

$$
Y_{A t}=\frac{\sigma}{P_{A t}^{C}}\left(w_{t} L_{t}+r_{X t} X_{t}+\mu r_{K t} K_{t}\right)
$$


The corresponding expression in the manufacturing sector is:

$$
Y_{M t}=(1-\sigma)\left(w_{t} L_{t}+r_{X t} X_{t}+\mu r_{K t} K_{t}\right)+\frac{1-\mu}{\xi} r_{K t} K_{t},
$$

where the second term on the right-hand-side comes from the demand for manufacturing goods left as bequests and is decreasing in the price of bequests.

In a closed economy, the relative price of agricultural goods is directly implied by the condition for wage equality $(12)$. The expression shows that the relative price of agricultural goods is proportional to manufacturing TFP, which increases with sound industrial policy. Agricultural goods are also relatively more expensive if land is scarce relative to capital and if there is a high share of labor employed in agriculture.

Combining (5), (12), (13) and (14) the relative labor allocation is given by:

$$
\frac{L_{A t}}{L_{M t}}=\frac{\sigma}{1-\sigma}\left(1-\alpha\left(\frac{1-\mu}{\xi}\right)\right) .
$$

As is standard in specific-factor models, the relative labor allocation across sectors is independent of factor endowments in autarky. This obtains since prices adjust in proportion to the labor share in the two sectors. The term $\sigma / 1-\sigma$ captures the relative demand for agricultural goods and is positively related to the share of labor in agriculture. A lower $\alpha$ indicates lower marginal returns to capital, and hence less resources devoted to bequests. Since bequests come from savings in terms of manufacturing goods, the demand for it decreases, as does $L_{M t}$. The same mechanism is at work if bequests are more costly, i.e. if $\xi$ is large. Alternatively, stronger preferences towards leaving bequests captured by a larger $(1-\mu)$ reflects more savings and therefore a higher demand for manufacturing goods and labor ${ }^{12}$

Equation (15) allows us to rewrite the price equation $(12)$ as:

$$
P_{A t}=\left(1+\pi_{M t} \gamma_{t}\right) A_{M t-1}\left(\frac{\sigma}{1-\sigma}\left(1-\alpha\left(\frac{1-\mu}{\xi}\right)\right) \frac{K_{t}}{X_{t}}\right)^{\alpha} .
$$

By using the price indices derived in Section 2.2. we may define the real returns to domestic capital and land, respectively, as $r_{D t} \equiv A_{K t} i_{K t} /\left(P_{A t}^{\mu \sigma} \xi^{1-\mu}\right)$ and $r_{X t} \equiv i_{X t} / P_{A t}^{\sigma}$. By using (5), (6), (11) and (16), we may derive the real returns to the domestic factors of production in Table 1.

The linear relationship between the real returns and the indirect utility of each type of elite immediately suggests that better economic institutions, i.e. higher $\pi_{M t}$, is beneficial for both landed

\footnotetext{
12 The allocation of labour would be a function of the relative preferences for agricultural versus manufacturing goods as in the standard model in the absence of bequests, i.e. $\mu=1$.
} 
Table 1: Real returns to the factors of production under each trade regime

Closed

Open

$$
\begin{array}{lll}
r_{D t} & \theta A_{K t} A_{M t}^{1-\mu \sigma} \frac{X_{t}^{\alpha \mu \sigma} L_{t}^{1-\alpha}}{\xi^{1-\mu} K_{t}^{1-\alpha(1-\mu \sigma)}} & \frac{\alpha A_{K t} A_{M t}^{1 / \alpha}}{\xi^{1-\mu} P_{A t}^{* \mu \sigma}}\left(\frac{L_{t}}{A_{M t}^{1 / \alpha} K_{t}+P_{A t}^{* 1 / \alpha} X_{t}}\right)^{1-\alpha} \\
r_{X t} & \phi A_{M t}^{1-\sigma} \frac{K_{t}^{\alpha(1-\sigma)} L_{t}^{1-\alpha}}{X_{t}^{1-\alpha \sigma}} & \alpha P_{A t}^{*(1-\alpha \sigma) / \alpha}\left(\frac{L_{t}}{P_{A t}^{* 1 / \alpha} X_{t}+A_{M t}^{1 / \alpha} K_{t}}\right)^{1-\alpha} \\
r_{F t} & \theta A_{M t}^{1-\mu \sigma} \frac{X_{t}^{\alpha \mu \sigma} L_{t}^{1-\alpha}}{\xi^{1-\mu} K_{t}^{1-\alpha(1-\mu \sigma)}} & \frac{\alpha A_{M t}^{1 / \alpha}}{\xi^{1-\mu} P_{A t}^{* \mu \sigma}}\left(\frac{L_{t}}{A_{M t}^{1 / \alpha} K_{t}+P_{A t}^{* 1 / \alpha} X_{t}}\right)^{1-\alpha} \\
\text { Notes: } \theta \equiv \frac{\alpha\left(\left(1+\frac{\sigma}{1-\sigma}\left(1-\alpha\left(\frac{1-\mu}{\xi}\right)\right)\right)\right)^{-(1-\alpha)}}{\left(\frac{\sigma}{1-\sigma}\left(1-\alpha\left(\frac{1-\mu}{\xi}\right)\right)\right)^{\alpha \mu \sigma}} \text { and } \phi \equiv \frac{\alpha\left(\frac{\sigma}{1-\sigma}\left(1-\alpha\left(\frac{1-\mu}{\xi}\right)\right)\right)^{1-\alpha \sigma}}{\left(1+\frac{\sigma}{1-\sigma}\left(1-\alpha\left(\frac{1-\mu}{\xi}\right)\right)\right)^{1-\alpha}} .
\end{array}
$$

and capitalist oligarchs, but through different channels. Industrial policies that spur manufacturing TFP raise the returns to capital by affecting capital's marginal productivity. Land returns also increase with growth-promoting industrial policies, but through a lower relative price of manufacturing. A higher price of bequests directly reduces returns to capital through $\xi$ and additionally decreases (increases) the marginal productivity of capital (land) by drawing workers into the agricultural sector. Moreover, relative abundance of capital with respect to land increases (decreases) returns to land (capital), while a larger labor stock increases the returns to both factors in their specific sectors.

\subsection{Open Economy}

In an open economy, the relative price of agricultural goods is exogenously given by the world relative price, $P_{A t}^{*}$. Imposing this condition on 12 implies that relative labor allocation across sectors is given by:

$$
\frac{L_{A t}}{L_{M t}}=\left(\frac{\left(1+\pi_{M t} \gamma_{t}\right) A_{M t-1}}{P_{A t}^{*}}\right)^{-1 / \alpha} \frac{X_{t}}{K_{t}}
$$

Under free trade in goods, the allocation of labor between the two sectors is influenced by factor endowments since the prices are fixed and cannot counterbalance them as they do in autarky. The relative allocation of labor is higher in manufacturing with better economic institutions, larger effective capital stock and higher world relative price of manufacturing goods.

In analogy to the closed economy, real returns in the open economy are defined as $r_{D t} \equiv$ $A_{K t} i_{K t} /\left(\xi^{1-\mu} P_{A t}^{* \mu \sigma}\right)$ and $r_{X t} \equiv i_{X t} / P_{A t}^{* \sigma}$. Using (5), (6), (11) and (17), real returns to capital and land in the open economy are displayed in Table 1 and provide insights on the effects of 
industrial policy under free trade, in relation to the sectoral allocation of labor. Capitalists benefit from strong economic institutions as this is conducive to technological progress and raises the marginal productivity of capital. More expensive bequests, however, disfavor capitalists and create a disincentive to save. By contrast, improved economic institutions hurt landowners by drawing labor out of agriculture, thereby decreasing the marginal productivity of land. In an open economy, landowners can satisfy their demand for manufacturing goods through imports, and internal prices are no longer relevant. Clearly, a higher world price of agricultural goods benefit landowners and translate into a loss for capitalists.

\section{Introducing International Capital Mobility}

We next introduce the possibility that the oligarchs can allow foreign, more productive, capital to flow into the country. We assume that returns generated from foreign capital, $K_{F t}$, are measured in terms of domestic goods and transferred back to the country of origin. The real returns to foreign capital are therefore $r_{F t} \equiv i_{F t} /\left(\xi^{1-\mu} P_{A t}^{\mu \sigma}\right)$ where $i_{F t}$ is given by 10 and $P_{A t}$ is given by 12 in a closed economy but equal to $P_{A t}^{*}$ in an open economy. We further let $r_{t}^{*}$ denote the real rate of return that can be obtained on international capital markets. Finally, we assume that $A_{K t}$ is a measure of the degree of spillovers generated by foreign capital inflows so that $A_{K t}=A_{K t}\left(K_{F t}\right)$, where $A_{K t}^{\prime}\left(K_{F t}\right)>0$. We start by discussing the equilibrium implications for the closed economy in Section 4.1 and proceed with the open economy in Section 4.2.

\subsection{Closed Economy}

The stock of foreign capital, $K_{F t}$, is governed by the potential returns it will generate in the country. The real returns to foreign capital in autarky are presented in the bottom row of Table 1, and calculated using 10 and $r_{D t}$ in a closed economy from the same table. Since $A_{K t}^{\prime}\left(K_{F t}\right)>0$, it follows directly that $\partial r_{F t} / \partial K_{F t}<0$. The opportunity cost for foreign investors is given by the returns to capital that prevail on the international market, $r_{t}^{*}$. Foreign capital enters the country only if returns are at least as high as $r_{t}^{*}$ until there are no arbitrage opportunities from investing in a particular country in equilibrium. Since $\partial r_{F t} / \partial K_{F t}<0$, it is sufficient to examine whether the latent return to the first unit of foreign capital entering the country, $\widetilde{r}_{F t} \equiv r_{F t} \mid K_{F t}=0$, satisfies this condition. Using $r_{F t}$ in a closed economy from Table 1 we can formulate the following Lemma: 
Lemma 1 In a closed economy, given that

$$
\widetilde{r}_{F t}=\theta\left[\left(1+\pi_{M t} \gamma_{t}\right) A_{M t-1}\right]^{1-\mu \sigma} \frac{L_{t}^{1-\alpha} X_{t}^{\alpha \mu \sigma}}{\left(A_{K t}(0) K_{D t}\right)^{1-\alpha(1-\mu \sigma)}}>r_{t}^{*},
$$

foreign capital will flow into the country until $r_{F t}=r_{t}^{*}$.

Proof. The lemma follows directly from the closed-economy $r_{F t}$ in Table 1 , setting $K_{F t}=0$. Capital flows into the country until the equilibrium level of foreign capital is reached at $r_{F t}=r_{t}^{*}$ :

$$
K_{F t}=\left[\theta\left[\left(1+\pi_{M t} \gamma_{t}\right) A_{M t-1}\right]^{1-\mu \sigma} L_{t}^{1-\alpha} X_{t}^{\alpha \mu \sigma} r_{t}^{*-1}\right]^{\frac{1}{1-\alpha(1-\mu \sigma)}}-A_{K t}\left(K_{F t}\right) K_{D t}
$$

In the expression for latent returns, $A_{K t}(0)$ is the lower-bound productivity of domestic capital that obtains in the absence of foreign capital. Since we assume that domestic capital is less productive than foreign capital we let $A_{K t}(0)$ be less than unity.

The Lemma suggests that countries promoting technological progress by maintaining strong economic institutions attract more capital, since the rate of return is higher in these countries. Countries with a large relative endowment of effective domestic capital $A_{K t} K_{D t}$, however, are characterized by lower returns to capital and are therefore less attractive to foreign investors. Likewise, circumstances that result in costly bequests deter foreign capital due to less demand for manufacturing goods and thus a non-progressing industrial sector. Finally, abundance in land attracts foreign capital in a closed economy through an increase in the relative price of manufacturing goods.

\subsection{Open Economy}

Real returns to foreign capital in an open economy are also presented in Table 1 and found analogously using (10), $r_{D t}$ in an open economy from the same table and $P_{A t}=P_{A t}^{*}$. The expression confirms that real returns to foreign capital are decreasing in the stock of foreign capital also in an open economy, so that $\partial r_{F t} / \partial K_{F t}<0$. As before, we may derive a latent return to the first unit of capital entering the economy and prove the following Lemma.

Lemma 2 In an open economy where the following condition holds:

$$
\widetilde{r}_{F t}=\frac{\alpha\left[\left(1+\pi_{M t} \gamma_{t}\right) A_{M t-1}\right]^{1 / \alpha}}{\xi^{1-\mu} P_{A t}^{* \mu \sigma}}\left[\frac{L_{t}}{P_{A t}^{* 1 / \alpha} X_{t}+\left[\left(1+\pi_{M t} \gamma_{t}\right) A_{M t-1}\right]^{1 / \alpha} A_{K t}(0) K_{D t}}\right]^{1-\alpha}>r_{t}^{*},
$$

foreign capital will flow into the country until $r_{F t}=r_{t}^{*}$. 
Proof. The lemma follows directly from the open-economy $r_{F t}$ in Table 1 , setting $K_{F t}=0$. Capital flows into the country until the equilibrium level of foreign capital is reached at $r_{F t}=r_{t}^{*}$ :

$$
K_{F t}=\left[\frac{\alpha\left(1+\pi_{M t} \gamma_{t}\right) A_{M t-1}}{\xi^{1-\mu} P_{A t}^{* \mu \sigma} r_{t}^{*}}\right]^{1 /(1-\alpha)} L_{t}-\left[\frac{P_{A t}^{*}}{\left(1+\pi_{M t} \gamma_{t}\right) A_{M t-1}}\right]^{1 / \alpha} X_{t}-A_{K t}\left(K_{F t}\right) K_{D t}
$$

The result suggests that appropriate industrial policies increase the likelihood of a positive inflow of capital in an open economy. Although better economic institutions increase the demand for labor in the economy, they also increase returns to manufacturing and the latter effect always dominates. Costly bequests could work as an opposing force that hampers the positive effect of productivityenhancing industrial policies and blocks the inflow of foreign capital. A smaller stock of effective domestic capital attracts foreign investors also in an open economy. In an open economy, the effect of more land is the opposite to that under autarky: instead of lowering prices, an increase in land lowers the marginal returns to capital by drawing workers out of manufacturing.

\section{Political Economy}

Having identified the equilibrium of the model for given economic institutions and trade and capital regimes, we now add a political layer and endogenize the oligarchs' policy choices. We consider two economies that differ only with respect to the endowments of the oligarchs, who may hold either land or capital. We refer to the regime as a land (capital) oligarchy if the elites are endowed with land (capital). As discussed in the introduction, imperfect political institutions have been modelled inter alia as rent seeking and expropriation in the previous literature. Here we assume that rents from the sector that is of no interest to the elites cannot be expropriated by the oligarchs. This is plausible if the rulers need to maintain order in the society in order to avoid a revolution and stay in power. In the same vein, Galiani and Torrens (2014) provide a rich model where different types of elites reallocate political power within their clique to avoid popular revolts.

The rulers have three policy instruments at their disposal. The oligarchs can prohibit trade, impose barriers to technology adoption by letting $\pi_{M t}<1$ according to (3), or block foreign capital inflows. For convenience, we define the following policy variables:

$$
\pi_{O t}=\left\{\begin{array}{c}
1 \text { if free trade } \\
0 \text { otherwise }
\end{array} \pi_{F t}=\left\{\begin{array}{c}
1 \text { if perfect capital mobility } \\
0 \text { otherwise }
\end{array}\right.\right.
$$

The rulers thus choose a policy vector, $\pi_{t}=\left(\pi_{O t}, \pi_{F t}, \pi_{M t}\right)$ to maximize their indirect utility. The 
optimal policy mix therefore satisfies:

$$
\pi_{h t}=\arg \max V_{h t}\left(\pi_{h t}\right)
$$

where $V_{h t}$ is given by (4) for $h=K, X$. Since the oligarchs' individual endowments, $\varkappa_{t}$, are given in each period, what matters to them is merely the real returns to the factors of production displayed in Table 1.

We next examine the optimal choices of the two types of oligarchs. As the simultaneous evaluation of all three policies is analytically intractable, we first analyse how trade interacts with economic institutions (Section 5.1) and second, how trade interacts with foreign capital inflows (Section 5.2) for each type of oligarchy. Numerical results on the simultaneous interplay between all three policies are then presented in Section 6.

\subsection{Trade and Economic Institutions}

We start by looking at the decision of the ruling oligarchs whether or not to open the economy to international trade given the policies on economic institutions and capital mobility. A capitalist oligarch prefers free trade if $V_{K t}\left(1, \pi_{F t}, \pi_{M t}\right)>V_{K t}\left(0, \pi_{F t}, \pi_{M t}\right)$. Using real returns to domestic capital under a closed and an open economy in Table 1, this inequality is satisfied when:

$$
\frac{1}{\left[P_{A t}^{* 1 / \alpha} X_{t}\right]^{\alpha \mu \sigma}} \frac{\left[\left[\left(1+\pi_{M t} \gamma_{t}\right) A_{M t-1}\right]^{1 / \alpha} K_{t}\right]^{1-\alpha(1-\mu \sigma)}}{\left[P_{A t}^{* 1 / \alpha} X_{t}+\left[\left(1+\pi_{M t} \gamma_{t}\right) A_{M t-1}\right]^{1 / \alpha} K_{t}\right]^{1-\alpha}}>\frac{\theta}{\alpha} .
$$

Stronger economic institutions, in terms of the industrial policy $\pi_{M t}$ that favors technological progress, increases the willingness of a capitalist oligarch to engage in trade by making manufacturing firms more competitive. In addition, more effective capital in the form of domestic capital growth, the inflow of foreign capital or an increase in the productivity of capital makes a capitalist oligarch more positive towards free trade. More expensive bequests that retard capital accumulation can erode the impact of industrial policy and thus delay the capitalists' decision to open up to trade (see Section 6). Positive changes in the world relative price of manufacturing goods, inversely measured by $P_{A t}^{* 1 / \alpha}$, also increases the willingness of a capitalist oligarch to engage in trade.

For a landed oligarch, the condition is instead $V_{X t}\left(1, \pi_{F t}, \pi_{M t}\right)>V_{X t}\left(0, \pi_{F t}, \pi_{M t}\right)$. Real returns to land in a closed and an open economy in Table 1 imply that this obtains when:

$$
\frac{\left[P_{A t}^{* 1 / \alpha} X_{t}\right]^{1-\alpha \sigma}}{\left[\left[\left(1+\pi_{M t} \gamma_{t}\right) A_{M t-1}\right]^{1 / \alpha} K_{t}\right]^{\alpha(1-\sigma)}\left[P_{A t}^{* 1 / \alpha} X_{t}+\left[\left(1+\pi_{M t} \gamma_{t}\right) A_{M t-1}\right]^{1 / \alpha} K_{t}\right]^{1-\alpha}}>\frac{\phi}{\alpha}
$$


The condition suggests that a landed oligarch is more inclined to trade when the absence of industrial policy entails weak economic institutions, the economy is relatively well-endowed with land (for reasons of comparative advantage) and when the world relative price of agricultural goods is high. We may formulate the following proposition.

Proposition 1 Given sufficiently weak economic institutions, an economy with a comparative disadvantage in manufacturing, i.e. with $K_{t} / X_{t}$ low enough to generate $P_{A t}<P_{A t}^{*}$, is opened up to trade if ruled by landed oligarchs, but remains closed under capitalist oligarchs.

Proof. Condition (18) does not hold for a sufficiently low level of $K_{t}$ since $K_{t}$ enters additively in the denominator and with a smaller exponent than in the numerator. A low level of $K_{t}$ is tantamount to a comparative disadvantage in manufacturing. By contrast, condition (19) does hold for a sufficiently low $K_{t}$ since $K_{t}$ appears only in the denominator.

Having established how oligarchs choose the trade regime for a given level of $\pi_{M t}$, we next investigate how they set industrial policy for a given trade regime $\pi_{O t}$. Equation (4) and real returns to domestic capital from Table 1 reveal that, regardless of the trade regime, it is optimal for a capitalist oligarch to promote industrial policy, since

$$
\frac{\partial V_{K t}\left(0, \pi_{F t}, \pi_{M t}\right)}{\partial \pi_{M t}}>0, \quad \frac{\partial V_{K t}\left(1, \pi_{F t}, \pi_{M t}\right)}{\partial \pi_{M t}}>0
$$

Intuitively, industrial policies that are conducive to technological progress in the manufacturing sector, raise the marginal productivity of capital and therefore always increase current returns to domestic capitalists. The extent of the impact of such policy on economic growth, however, depends on the cost of bequests.

Turning to the choice of a landed oligarch, equation (4) and the real returns to domestic capital from Table 1 imply:

$$
\frac{\partial V_{X t}\left(0, \pi_{F t}, \pi_{M t}\right)}{\partial \pi_{M t}}>0, \quad \frac{\partial V_{X t}\left(1, \pi_{F t}, \pi_{M t}\right)}{\partial \pi_{M t}}<0
$$

A landed oligarch thus prefers strong economic institutions in autarky, but weak economic institutions when the economy is open to trade. Intuitively, industrial policies that promote manufacturing TFP reduce the relative price of manufacturing goods in a closed economy, which benefits the landed elites by raising returns to land. In an open economy, no such price effect can arise since the relative price is determined in the world market. In a globalized setting, weaker economic institutions reduce manufacturing TFP growth and therefore the marginal productivity of labor 
employed in that sector. This leaves more workers in agriculture, which spurs returns to land and benefits landowners. Interestingly, this suggests that globalization changes the incentives of the landed oligarchs in a way that is detrimental for industrial growth.

Proposition 2 A capitalist oligarch always seeks to strengthen economic institutions regardless of whether the country is closed or open to trade. A landed oligarch supports industrial policy conducive to technology adoption in autarky but blocks improvements in economic institutions in an open economy.

Proof. The proposition follows directly from the differentiation of real returns to land and domestic capital in Table 1 with respect to $\pi_{M t}$.

\subsection{Trade and Foreign Capital Inflows}

We now turn to the ruling oligarchs' decision of whether or not to allow for the inflow of foreign capital under different trade regimes. On the entry of foreign capital, what matters is not only how the oligarchs set $\pi_{F t}$, but also whether returns are such that the country is able to attract foreign capital. This implies that $\pi_{F t}$ and $\pi_{M t}$ interact in important ways. In this section, we consider the choice of $\pi_{F t}$ for a given trade regime and for a given industrial policy.

Starting with the optimal policies of a capitalist oligarch, the results in Table 1 show that the effect of foreign capital on the returns to domestic capital is ambiguous in a closed economy. Foreign capital enters the denominator of domestic returns to capital due to diminishing marginal returns. However, foreign capital also enters the numerator through its technological spillovers on domestic capital, captured by $A_{K t}\left(K_{F t}\right)$. A capital oligarchy thus only favors capital inflows if the gains from the productivity spillovers dominate the losses from the direct reduction in the marginal productivity of capital, i.e.

$$
\frac{d V_{K t}}{d K_{F t}}>0 \text { if } \frac{\partial V_{K t}}{\partial A_{K t}} \frac{\partial A_{K t}}{\partial K_{F t}}>\frac{\partial V_{K t}}{\partial K_{F t}} .
$$

Differentiating (4) with respect to $K_{F t}$, using real returns to capital under each trade regime in Table 1 , we find that $V_{K t}\left(0,1, \pi_{M t}\right)>V_{K t}\left(0,0, \pi_{M t}\right)$ when

$$
\frac{d V_{K t}\left(0, \pi_{F t}, \pi_{M t}\right)}{d K_{F t}}>0 \text { for } \psi_{t}>(1-\alpha(1-\mu \sigma)) \equiv \psi_{t}^{c}
$$

where $\psi_{t} \equiv K_{D t} A_{K t}^{\prime}(0) /\left(1+K_{D t} A_{K t}^{\prime}(0)\right) \in[0,1]$ is an index of potential spillovers from foreign capital at the point where no foreign investment has yet taken place in the country. In the open 
economy, condition $V_{K t}\left(1,1, \pi_{M t}\right)>V_{K t}\left(1,0, \pi_{M t}\right)$ is instead satisfied when

$$
\frac{d V_{K t}\left(1, \pi_{F t}, \pi_{M t}\right)}{d K_{F t}}>0 \text { for } \psi_{t}>(1-\alpha) \frac{\left[\left(1+\pi_{M t} \gamma_{t}\right) A_{M t-1}\right]^{1 / \alpha} A_{K t}(0) K_{D t}}{\left(P_{A t}^{* 1 / \alpha} X_{t}+\left[\left(1+\pi_{M t} \gamma_{t}\right) A_{M t-1}\right]^{1 / \alpha} A_{K t}(0) K_{D t}\right)} \equiv \psi_{t}^{o},
$$

from which we can deduce the following Lemma:

Lemma 3 The threshold level of spillovers above which the capitalist oligarchs choose to allow the inflow of foreign capital are higher in a closed economy than in an open economy, i.e.

$$
\psi_{t}^{c}>\psi_{t}^{o}
$$

Proof. In (21), it is easy to see that $\psi_{t}^{o}<1-\alpha$, and since $1-\alpha<(1-\alpha(1-\mu \sigma)),(20)$ and (21) together imply $\psi_{t}^{c}>\psi_{t}^{o}$.

Lemma 3 suggests that all else equal, a capitalist oligarch is more in favor of foreign capital inflows in an open economy than in a closed economy. Thus, as long as spillovers are sufficiently large to satisfy (21), the oligarchs choose to allow for capital mobility when open to trade but not in autarky. We can therefore conclude from the results that trade and capital mobility are complementary policies in a capital oligarchy.

The choice of the landed oligarch is more straightforward. Real returns to land for each trade regime in Table 1 imply that a landowner is in favor of the entry of foreign capital in a closed economy, but against it in an open economy 13

$$
\begin{aligned}
& \frac{d V_{X t}\left(0, \pi_{F t}, \pi_{M t}\right)}{d K_{F t}}>0 \Rightarrow V_{X t}\left(0,1, \pi_{M t}\right)>V_{X t}\left(0,0, \pi_{M t}\right), \\
& \frac{d V_{X t}\left(1, \pi_{F t}, \pi_{M t}\right)}{d K_{F t}}<0 \Rightarrow V_{X t}\left(1,0, \pi_{M t}\right)>V_{X t}\left(1,1, \pi_{M t}\right) .
\end{aligned}
$$

A landed oligarch is thus more in favor of foreign capital inflows in a closed economy than in an open economy. Trade and capital mobility are thus substitute policies in a land oligarchy. ${ }^{14}$ The findings can be summarized in the following proposition:

Proposition 3 Free trade and capital mobility are complementary policies in a capital oligarchy but substitute policies in a land oligarchy.

\footnotetext{
${ }^{13}$ Note that very high levels of $\psi_{t}$, at which the landed autocrat would favour capital inflows also in autarky, are not relevant for our analysis. In such cases excessive spillovers discourage foreign investors, as can be seen from $A_{K t}$ appearing in the denominator of the latent returns to foreign capital and entering negatively in the equilibrium level of foreign capital in the proofs of Lemmas 1 and 2

${ }^{14}$ Moreover, since we know from Proposition 1 that the landed oligarchs maintain weak economic institutions when open to trade, foreign investors would be less likely to invest in the country, even if they were allowed to do so.
} 
Proof. The result for a capital oligarchy follows from (20), 21) and in turn from Lemma 3. The result for a land oligarchy is obtained by differentiating (4) with respect to $K_{F t}$ using the returns to land in Table 1.

The mechanism that causes policies on trade and capital inflows to be substitutes in a land oligarchy is closely linked to the result in Proposition 2. In a closed economy, a larger capital stock (and more efficient domestic capital) raises the relative price of agricultural goods and hence the real income of a landowner. Under free trade, however, a larger capital stock will affect the sectoral allocation of workers to the disadvantage of landowners. For a capital oligarchy, the problem is very different. The inflow of foreign capital potentially has three effects on domestic capitalists and these effects go in opposite directions as far as the real returns to capital are concerned. The positive effect of foreign capital is that it causes technological spillovers that raise the productivity of domestic capital. The two negative effects are, first, that, for a given allocation of labor, more capital implies more capital per worker in the manufacturing sector and this lowers the marginal productivity of all capital. Second, the foreign capital increases the supply and lowers the relative price of manufacturing goods. In autarky, all three effects are present. Under free trade, however, the third effect disappears since relative prices are fixed. Therefore, a capitalist oligarch is more likely to favor capital inflows under free trade than under autarky.

\section{The Evolution of the Economy}

To illustrate the simultaneous interaction between industrial policy, goods trade and the inflow of foreign capital, we next display numerical solutions to the model. We solve for the optimal policies in each period and simulate the economy over time. We start out in a state where the economy holds a comparative disadvantage in manufacturing and study the decision in each oligarchy to open up to trade and allow for foreign capital inflows. When possible, we try to match key statistics for the South Korean economy in parameterizing the model and therefore think of the capital oligarchy as a crude representation of this economy. For the same parameterization, we then conduct two counterfactual experiments and study (i) how South Korea would have evolved had its elite been landowners rather than capitalists and (ii) how South Korea would have evolved if the price of bequests had exceeded that of manufacturing goods, thus creating an environment less conducive to capital accumulation. 


\subsection{Parameters}

In parameterizing the model, we set the capital share in manufacturing, and thus the land share in agriculture, to match the average labor share of .703 reported for the South Korean economy over the period 1966-90 by Young (1995), and let $\alpha=.297$. In choosing the consumption share of income, $\mu$, we note that bequests correspond to domestic investments in our setting. We thus set $\mu$ to match the .081 investment share of GDP in South Korea in 1960, obtained from the Penn World Tables 7.1, and let $\mu=.919$. We have no prior on how to set the agricultural share of consumption but let $\sigma=.10$ in the benchmark simulation. In modelling the growth process of manufacturing TFP, we follow Hansen and Prescott (2002) in choosing an average annual growth rate of 1.4 per cent. Since one model period spans one generation, we convert these annual rates to 30-year equivalents and let $\gamma=.518 .15$

We also need estimates of the population shares. To the best of our knowledge, direct estimates of the share of landowners and capitalists in South Korea are not available, but since these households represent the potential elites, they are bound to be a small number. In the benchmark we want to make the two groups of elites equally influential in their respective economies and therefore set $N_{X}=N_{K}=.05$. Since the population is normalized to one, this implies $L=.90$. As stated in the theoretical section, each landowner holds one unit of land, which implies that the total land endowment in the economy is $X_{t}=N_{X}=.05$.

We have no prior on how to set the international relative price of agricultural goods but since we want to mimic South Korea's transition from a closed to an open economy, we make sure that the economy starts out with a comparative disadvantage in manufacturing by ensuring that $P_{A}^{*}<P_{A 0}$, and let $P_{A}^{*}=1$. The final set of parameters are related to the inflow of foreign capital. We choose a simple, linear relation between $K_{F}$ and $A_{K}$ and assume:

$$
A_{K}=\kappa_{1}+\kappa_{2} K_{F t}
$$

where $\kappa_{1} \in(0,1)$ and $\kappa_{2}>0$. Since we want domestic capital to be less productive than foreign capital when $K_{F t}=0$ and spillovers from foreign capital to be positive, we let $\kappa_{1}=.80$ and $\kappa_{2}=2$. We set the international real interest rate such that foreign investors would like to invest in the capital oligarchy, given the opportunity to do so, and let $r^{*}=6$.

\footnotetext{
${ }^{15}$ This is a conservative estimate. An alternative would be to set the annual TFP growth rate to match the average annual growth rates of 3 percent over the period 1966-90, as reported in Table VII in Young (1995). However, since we think of the starting date for our experiment as pre-1960 we opt for a more modest growth rate. Moreover, we wish to study how policy choices affect the evolution of the two types of autocracies and thus seek to minimize the exogenous influence on the economies.
} 
Table 2: Optimal policies in the three different oligarchies.

\begin{tabular}{llllllllllll}
\hline \hline & $t$ & 1 & 2 & 3 & 4 & 5 & 6 & 7 & 8 & 9 & 10 \\
& & & & & & & & & & & \\
\hline \multirow{2}{*}{ Capital oligarchy, $\xi=1$} & $\pi_{O t}$ & 0 & 0 & 1 & 1 & 1 & 1 & 1 & 1 & 1 & 1 \\
& $\pi_{F t}$ & 0 & 0 & 0 & 0 & 0 & 0 & 0 & 0 & 1 & 1 \\
& $\pi_{M t}$ & 1 & 1 & 1 & 1 & 1 & 1 & 1 & 1 & 1 & 1 \\
& & & & & & & & & & & \\
Land oligarchy & $\pi_{O t}$ & 1 & 1 & 1 & 1 & 1 & 1 & 1 & 1 & 1 & 1 \\
& $\pi_{F t}$ & 0 & 0 & 0 & 0 & 0 & 0 & 0 & 0 & 0 & 0 \\
& $\pi_{M t}$ & 0 & 0 & 0 & 0 & 0 & 0 & 0 & 0 & 0 & 0 \\
& & & & & & & & & & & \\
Capital oligarchy, $\xi=5$ & $\pi_{O t}$ & 0 & 0 & 0 & 1 & 1 & 1 & 1 & 1 & 1 & 1 \\
& $\pi_{F t}$ & 0 & 0 & 0 & 0 & 0 & 0 & 0 & 0 & 0 & 0 \\
& $\pi_{M t}$ & 1 & 1 & 1 & 1 & 1 & 1 & 1 & 1 & 1 & 1 \\
& & & & & & & & & & & \\
\hline
\end{tabular}

\subsection{Results}

Table 2 displays the optimal policies from the benchmark experiment in the three types of oligarchies: our benchmark capital oligarchy, a land oligarchy and a capital oligarchy with the price of bequests being five times that of manufacturing. To understand how these policies affect the comparative advantage of the economies, it is useful to simultaneously study the impact of these policies on the evolution of the relative price of agricultural goods, displayed in Figure 1. The benchmark capitalist oligarchy starts out with a comparative disadvantage in manufacturing, so that the relative price of agricultural goods in this economy is lower than the world-market price $P_{A}^{*}$. Consequently, the capitalist oligarchs initially maintain a closed economy. As shown in Table 2, the oligarchs continue to strengthen economic institutions and set $\pi_{M}$ to one. The strong industrial policy promotes technological progress and spurs manufacturing TFP growth, which gradually shifts the comparative advantage of this economy from agriculture to manufacturing. Figure 1 suggests that in period 3, the relative price of agricultural goods has become higher than the world-market price of these goods in the capital oligarchy. This implies that the relative price of manufacturing goods now has become lower than the world-market price on these goods, i.e. the economy has developed a comparative advantage in manufacturing. This makes the capitalist oligarchs favour trade openness and set $\pi_{O}=1$ from period 3 onwards. The upper panel of Figure 2 displays the evolution of domestic capital, the inflow of foreign capital, the implied relative productivity of domestic capital and the total effective capital stock in this economy. The graphs suggest that the 


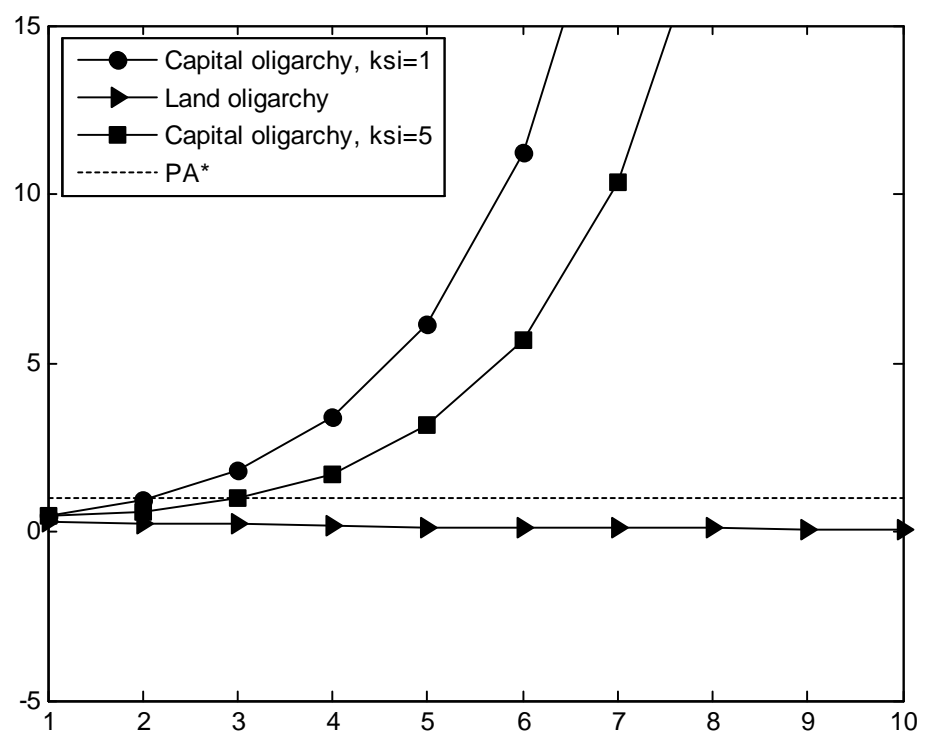

Figure 1: The relative price of agricultural goods in the three economies.

strong economic institutions promote domestic capital accumulation by generating high returns to this factor. Turning to the decision whether or not to allow the inflow of foreign capital, the results in Table 2 suggest that the oligarchs allow for such inflows from period 9 onwards. The reason is that the potential spillovers from such capital, as captured by $\psi_{t}$ in (21), is increasing in domestic capital. Once the oligarchs decide to set $\pi_{F}=1$, the strong industrial policy and high returns to capital have made the economy attractive to investors and foreign capital will flow into the country. As shown in Figure 2, the inflow of foreign capital boosts the total effective capital stock through two channels: in addition to having a direct effect on $K$, it increases the relative productivity of domestic capital.$^{16}$ Moreover, the increase in the productivity of domestic capital will dampen some of the fall in returns generated by a growing capital stock. This feature of the model is consistent with Hsieh (2002), who shows how technological spillovers from the inflow of foreign capital can prevent a fall in the returns to capital and trigger further investment in the economy. Figure 3 reports the evolution of GDP over time. The graph shows that the capital oligarchy grows at a steady but moderate pace for the first 8 periods. Once foreign capital is allowed into the country in period 9, however, the growth rate increases dramatically and boosts GDP 17

\footnotetext{
${ }^{16}$ The sharp increase in $A_{K t}$ in period 9 gives substantial leverage to the $A_{K t} K_{D t}$ term towards the end of the simulation, causing sustained growth in $K_{t}$ despite the modest increase in $K_{D t}$.

17 Additional results, available on request, reveal that in the absence of positive spillovers from foreign capital, GDP in the capital oligarchy continues to grow steadily but without the distinct acceleration displayed in Figure 3 .
} 

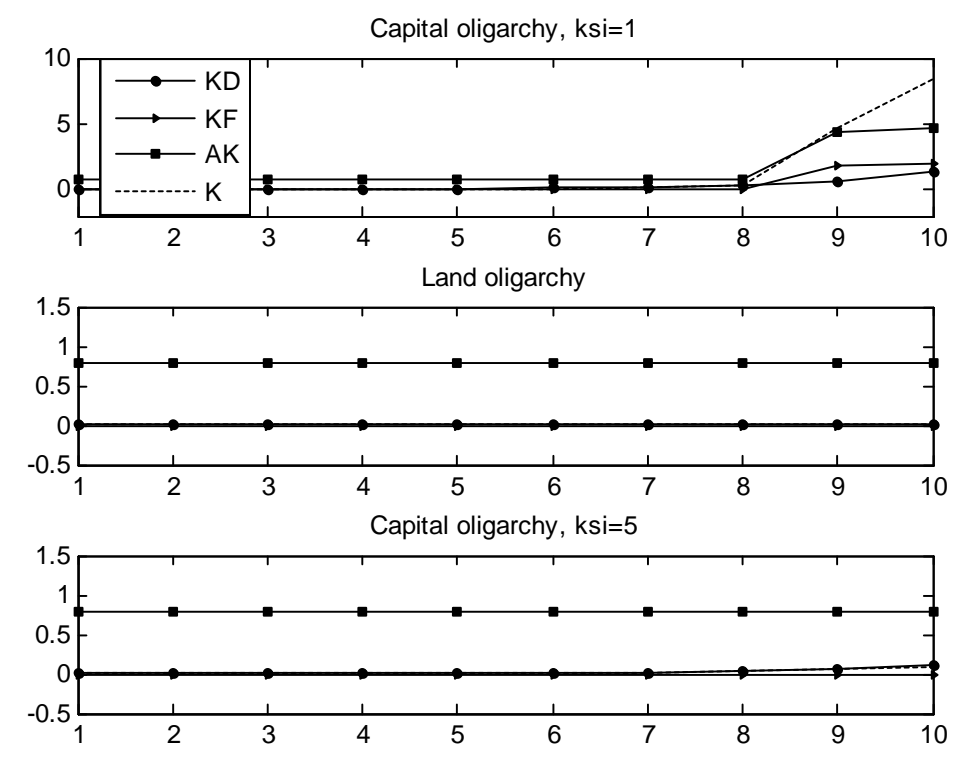

Figure 2: Capital accumulation in the three economies.

We next consider the evolution of the same economy, but under the rule of landed oligarchs. Since the economy starts out with a comparative advantage in agriculture, the landed oligarchs open up to trade immediately as the relative price of agriculture is lower than the relative worldmarket price of these goods. The results in Table 2 indicate that the landed oligarchs set $\pi_{O}=1$ from period 1 onwards and Figure 1 corroborates that $P_{A}<P_{A}^{*}$ in this economy. Consistent with Proposition 2, the results in Table 2 show that in this open environment, the land oligarchy neglects economic institutions and sets $\pi_{M}$ to zero. The barriers to technological progress that ensue cause manufacturing TFP to stagnate. The graph in Figure 1 reveals that the lack of growth in manufacturing productivity implies that the relative price of agriculture that would prevail in autarky decreases slightly over time and that the comparative advantage is never overturned 18 The middle panel of Figure 2 shows that the weak industrial policy that is sustained in this open economy is detrimental to capital formation. The absence of growth in manufacturing TFP generates low returns to capital and deters capital accumulation. Consistent with Proposition 3, it is never optimal for the landed oligarchs to allow for foreign investment. The graph of GDP in Figure 3 confirms that the weak industrial policy, constant manufacturing TFP and failure to encourage capital accumulation, constitute a path toward stagnation.

\footnotetext{
${ }^{18}$ To allow for some TFP-growth also in the land oligarchy, we could set $\pi_{M}$ at some lower bound, slightly greater than zero, so that the elites cannot block all technological progress in manufacturing. However, whether we set $\pi_{M}$ to zero or to some arbitrarily small number does not matter for the main results or for comparisons across regimes.
} 


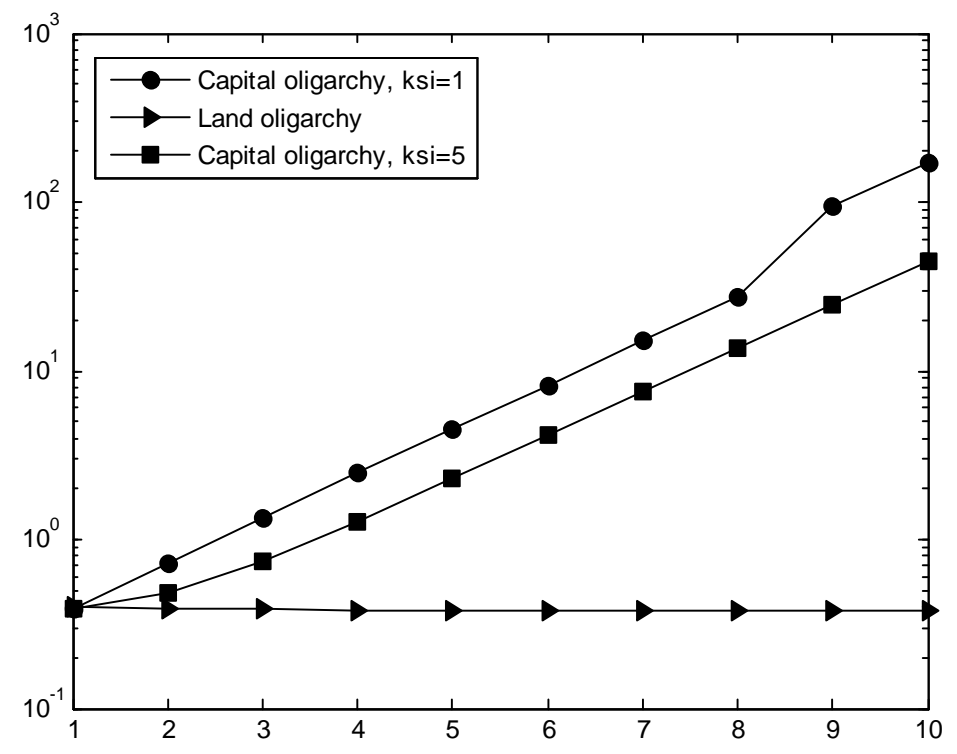

Figure 3: The evolution of GDP in the three economies.

Finally, we consider the effect of a higher price of bequests on capital accumulation in an oligarchy run by capitalists. Letting $\xi=5$ the price of bequests becomes five times that of manufacturing goods, creating an environment detrimental to saving. The graph in Figure 1 confirms that the moderate capital growth delays the shift in comparative advantage towards manufacturing so that it will be optimal for the oligarchs to open up to trade only at a later stage of development. The results in Table 1 confirm that this alternative capital oligarchy opens up to trade only in period 4. Trade liberalization is thus delayed by an entire generation. The bottom panel of Figure 2 illustrates the weak performance of this economy in terms of capital accumulation. Domestic capital grows at a very moderate pace and it is never optimal for the oligarchs to allow for foreign investment within the time frame of the simulation, i.e. 10 generations. The growth acceleration that occurs in the benchmark capital oligarchy therefore fails to manifest in this counterfactual economy. The results are corroborated by the GDP plot in Figure 3. The capital oligarchy with expensive bequests represents a middle ground between the benchmark capital oligarchy that is conducive to saving and the economy ruled by land oligarchs.

Additional results, available on request, show that a higher price of bequests delays the process even more: when $\xi=100$ the oligarchs open up to trade in period 6 and when $\xi=500$ trade liberalization does not occur until period 7. In the extreme case when the price of bequests tends to infinity $(\xi=100000)$, the capitalist oligarchy remains closed to trade throughout the time frame 
of the experiment. The results suggest that being ruled by capitalist oligarchs is no panacea for a successful ISI-process: an environment conducive to saving must also be in place for a comparativeadvantage reversal to occur.

\section{Discussion}

Historical accounts suggest that the politically influential group of any country tends to be in possession of the economy's natural resources. In industrialized economies with a developed business sector, the elites tend to be capitalists who derive profits from manufactures. South Korea is an example of an economy where the powerful industrial families of the Jaebols constituted a politically influential group from the 1950s onwards, see for instance Kim (1976). The strong influence of capitalists and bankers in Shanghai under the Kuomintang regime in the late 1920s is also well documented (Coble, 1979). In traditionally agrarian economies, such as Argentina in the 19th century, the political power of landowners is undisputed, see for instance Taylor (1997). However, the emergence of the industrial elite after the interwar period changed the balance of power which then came to oscillate between the two elites (Galliani and Torrens, 2014).

As discussed above, it is often believed that the autocratic governments in South Korea and Taiwan were heavily influenced by industrialists and the financial industry. Rodrik (1994) emphasizes that the governments in these economies prioritized industrial development and sought to affect their comparative advantage by various policy measures. The GDP per capita levels in these two countries were in 1960 on par with those in many sub-Saharan countries and well below those of several large Latin American countries such as Brazil, Argentina or Mexico. During the following three decades, however, the average growth rates of GDP per capita have averaged almost 7 percent. The cases of Taiwan and South Korea closely follow our predictions. In the 1960s, domestic levels of investment rose sharply and many have argued that this rise in investment was strongly connected to government policy. Rodrik (1994) writes:

“... in the early 1960s and thereafter the Korean and Taiwanese governments managed to engineer a significant increase in the private return to capital. They did so not only by removing a number of impediments to investment and establishing a sound investment climate, but more importantly by alleviating a coordination failure which had blocked economic take-off". (p. 2)

Importantly, however, export-to-GDP ratios remained relatively low throughout the 1960s but 
rose sharply, in fact almost doubled, during the early 1970s. The 1970s and the 1980s were also the decades when Taiwan started to receive large inflows of foreign direct investment ${ }^{19}$ These two countries thus remained closed well into the 1960s, while the capital stock and competitiveness grew. In time, however, the rulers in these countries found it favourable to enter world markets and started to allow for foreign capital inflows. This sequence of events: i) low levels of trade and FDI but high levels of investment and TFP growth before the 1970s; ii) opening up to trade in the early 1970s; and iii) substantial capital inflows during the later 1970s and 1980s, follows our model's predictions very closely.

The model's predictions for the land oligarchy are broadly consistent with the evolution of the landed Latin American economies of the 19th century. These economies opened up to trade at an early stage of development, focusing on exports of primary goods. Since the elites were predominantly landowners in these economies, the model provides a rationale for why they favoured globalization early on. The model is also consistent with the weak economic institutions that were a feature of the Latin American landscape at the time and can help explain why the region failed to attract foreign investors 20

Further, the example of the capital oligarchy with expensive bequests helps shed light on some of the mechanisms affecting the likelihood of successful ISI. By varying the price of bequests we may compare the unparalleled East Asian experience to postwar Argentina prior to the coup of 1976. In Argentina, the Perónists brought about a conflict of interest concerning trade policy and put an end to the country's history of liberal trade policies. Industrial elites, supported by industrial workers, opted for protectionist policies that would prove unsuccessful in generating sustainable growth. Consistent with the model's predictions, the economy remained on the brink of autarky until the military government, backed by the rural elite, took over in 1976 and opened up to trade. 21

\footnotetext{
${ }^{19}$ See footnote 5

20 Several studies addressing the stagnation of Latin America identify the concentration of land ownership as a possible culprit, see for instance Persson and Tabellini (1994), Engerman and Sokoloff (2000) and Adamopoulos (2008). Galor, Moav and Vollrath (2009) show that inequality in land ownership may be detrimental to the emergence of institutions promoting human capital and may therefore delay industrialization. On a similar note, Galiani et al. (2008) study investments in public education in economies governed by landlords who do not engage in the production of manufacturing goods. They argue that such economies fail to sustain strong educational institutions since the elites do not benefit from more educated workers.

21 The model falls short of explaining, however, why industrial policies conducive to growth in the manufacturing sector were not implemented during this era. It may well be that our simplifying assumption that industrial policies are costless plays a key role in this regard. Introducing a trade-off between the benefits of industrial policies and the costs that they incur could plausibly explain why the Perón administration did not strengthen institutions as predicted by the model. An interesting way of generating predictions consistent with actual developments in Perónist Argentina would be to directly link the higher price of bequests to a higher cost of industrial policies and therefore
} 
In sum, the most common views on the development of South Korea, Taiwan and Argentina are largely consistent with our model. Building a model that is in line with the consensus view of the factor endowments of the political elites in these countries, we demonstrate how the interaction between industrial policy and trade in goods and capital is capable of generating sequences of events in accordance with actual developments in these economies. By varying the price of bequests, the model is able to endogenously explain why ISI policies have been successful in some countries but not in others: in addition to implementing industrial policies that promote technological progress in the manufacturing sector, institutions must be such that bequests are inexpensive and hence conducive to capital accumulation.

\section{Concluding Remarks}

In this paper we present a specific-factor model of an economy where the ruling oligarchs may or may not strengthen technology-promoting institutions, open up to trade and allow for foreign capital inflows. We argue that the endowments of the ruling oligarchs can have far-reaching effects on the economy's long-run development. The framework shows that economic institutions in terms of industrial policy and openness to trade in goods and capital interact in ways that may help explain the heterogeneous performance of economies with imperfect political institutions.

We illustrate the workings of the model by simulating an economy that starts out with a comparative disadvantage in manufacturing and vary the assumption about the nature of the political elites. We find that if the oligarchs are endowed with capital, they are likely to maintain a closed economy while strengthening economic institutions. The continuous promotion of sound industrial policy will lead to capital accumulation and a gradual shift towards a comparative advantage in manufacturing that eventually will make the oligarchs favour international trade. The strong economic institutions will make the economy attractive to foreign investors and productive capital will flow into the country and spur the accumulation of effective capital. In a capital oligarchy, trade in goods and capital are thus complementary policies that will lead to rapid growth and longterm development. We argue that our results for the capital oligarchy are consistent with actual developments in the Tiger Economies of South Korea and Taiwan during the postwar period.

If the oligarchs are instead endowed with land, they are likely to embrace globalization at an

early stage. Opening up to trade, however, creates an adverse incentive not to improve economic weaker economic institutions. 
institutions or allow for foreign capital inflows, which discourages capital accumulation. In such a land-oriented oligarchy, allowing for trade and foreign capital inflows are substitute policies and, due to the weak industrial policy that ensues, the economy is bound to stagnate over time. We argue that the results for the land oligarchy are broadly consistent with the developments in Argentina during the pre-Perónist era and during the military rule of the $1980 \mathrm{~s}{ }^{22}$

Finally, we show that implementing ISI-policies favoring the manufacturing sector is no guarantee for successful growth. ISI-policies may fail if investments are too costly and thus discourage capital accumulation. Under such circumstances, capitalist oligarchies liberalize trade at a later stage and are less likely to be attractive to foreign investors.

We have chosen to model an oligarchy rather than a democracy since this simplifies the politicaleconomy layer of the model. However, our results would obtain also in a democracy where the political elites could form a political lobby and exert pressure on the democratic leader. The results could thus be derived from a more general framework with imperfect political institutions ${ }^{23}$ The model can be extended in several interesting dimensions. It would be interesting to study the foundations of institutions in greater detail and to add microfoundations for firms' incentives to invest in new technology. Another possibility would be to introduce a number of explicit trade policies and let the ruling oligarchs set tariffs.

\footnotetext{
${ }^{22}$ Our results are in line with Matsuyama (1992), who also considers growth in the agricultural sector. He shows that in a closed economy, there is a positive link between agricultural productivity and economic growth, whereas for a small open economy the relationship is negative. Having growth in agriculture would thus amplify our results that a land autocracy that opens up to trade at an early stage of development is bound for stagnation, while a closed capital autocracy investing in sound industrial policy is bound to prosper.

${ }^{23}$ See for instance Levchenko (2013) for a framework with political lobbying or Galiani and Torrens (2014) for a model of conflict between the elites.
} 


\section{References}

[1] Acemoglu, D. and Robinson, J.A. (2006), Economic Origins of Dictatorship and Democracy, Cambridge: Cambridge University Press.

[2] Acemoglu, D., Johnson, S. and Robinson, J. (2005a), "Institutions as a Fundamental Cause of Long-Run Growth", In Handbook of Economic Growth, Vol. 1A., Aghion, P. and Durlauf, S.N. (Eds.), Elsevier, Amsterdam, pp. 385-472.

[3] Acemoglu, D., Johnson, S. and Robinson, J. (2005b), "The Rise of Europe: Atlantic Trade, Institutional Change, and Economic Growth", American Economic Review, Vol. 95, No.3, pp. 546-579.

[4] Adamopoulos, T. (2008), "Land Inequality and the Transition to Modern Growth", Review of Economic Dynamics, 11, pp. 257-282.

[5] Ades, A and Di Tella, R. (1999), "Rents, Competition, and Corruption", American Economic Review, Vol. 89, pp. 982-993.

[6] Albornoz, F., Galiani, S. and Heymann, D. (2012), "Foreign Investment and Expropriation under Oligarchy and Democracy", Economics $\mathscr{E}$ Politics, 24, pp. 24-46.

[7] Bardhan, P. (2010), "Reflections on some Under-researched Issues in Trade and Development", keynote lecture given to IGC Trade group at Columbia.

[8] Brambilla, I., Galiani, S. and Porto, G. (2010), "Argentine Trade Policies in the XX Century: 60 Years of Solitude", forthcoming in Argentine Exceptionalism, Glaeser, E. and Di Tella, R. (Eds.), JFK Harvard University.

[9] Cervelatti, M., Naghavi, A. and Toubal, F. (2013), "Trade Liberalization, Democratization, and Technology Adoption", IZA Discussion Paper No. 7132.

[10] Coble, P.M. (1979), "The Kuomintang Regime and the Shanghai Capitalists", The China Quarterly, No. 77, pp. 1-24.

[11] Do, Q-T., and Levchenko, A.A. (2009), "Trade, Inequality, and the Political Economy of Institutions," Journal of Economic Theory, Vol. 144, pp. 1489-1520. 
[12] Engerman, S.L. and Sokoloff, K.L. (2000), "Institutions, factor endowments, and paths of development in the New World", Journal of Economic Perspectives, 14 (3), pp. 217-232.

[13] Falkinger, J. and Grossman, V. (2005), "Institutions and Development: The Interaction between Trade Regime and Political System", Journal of Economic Growth, 10, pp. 231-272.

[14] Falkinger, J. and Grossman, V. (2013), "Oligarchic land ownership, entrepreneurship, and economic development", Journal of Development Economics, 101, pp. 206-215.

[15] Galiani, S., Heymann, D., Dabus, C. and Tohme, F. (2008), "On the Emergence of Public Education in Land-rich Economies", Journal of Development Economics, 86, pp. 434-446.

[16] Galiani, S. and Torrens, G. (2014), "Autocracy, Democracy and Trade Policy", Journal of International Economics, 93, pp. 173-193.

[17] Galor, O., Moav, O. and Vollrath, D. (2009), "Inequality in Landownership, the Emergence of Human-Capital Promoting Institutions, and the Great Divergence", Review of Economic Studies, Vol. 76 (1), pp. 143-179.

[18] Hansen, G.D. and Prescott, E.C., (2002), "Malthus to Solow", American Economic Review, 92(4), pp. 1205-1217.

[19] Hong, W. (1980), "Export Promotion and Employment Growth in South Korea", in Krueger, A.O., Lary, H.B., Monson, T. and Akrasanee, N. (Eds.) Trade and Employment in Developing Countries, 1: Individual Studies, National Bureau of Economic Research, pp. 341-392

[20] Hsieh, C.T. (2002), "What Explains the Industrial Revolution in East Asia? Evidence from the Factor Markets", American Economic Review, 92 (3), pp. 502-526.

[21] Johnson, S., Ostry, J., and Subramanian, A. (2007), "The Prospects for Sustained Growth in Africa: Benchmarking the Constraints", IMF Working Paper 07/52.

[22] Jones, R.W. (1971), "A three-factor model in theory, trade and history", In Bhagwati, J. et al., eds., Trade, Balance of Payments and Growth, Amsterdam: North-Holland.

[23] Jones, R.W. and Neary, J.P. (1984), "The Positive Theory of International Trade", In Handbook of International Economics, Vol. 1, ed. R.W. Jones and P.B. Kenen, Amsterdam: NorthHolland. 
[24] Jones, R.W. (1989), "Co-movements in Relative Commodity Prices and International Capital Flows: A Simple Model", Economic Inquiry, Vol. 27 (1), pp. 131-141.

[25] Kim, K-D. (1976), "Political Factors in the Formation of the Entrepreneurial Elite in South Korea", Asian Survey, Vol. 16, No. 5, pp. 465-477.

[26] Levchenko, A.A. (2007), "Institutional Quality and Trade", The Review of Economic Studies, Vol. 74, No.3, pp. 791-819.

[27] Levchenko, A.A. (2013), "International Trade and Institutional Change", Journal of Law, Economics, and Organization, Vol. 29, No. 5, pp. 1145-1181.

[28] Matsuyama, K. (1992), "Agricultural Productivity, Comparative Advantage, and Economic Growth", Journal of Economic Theory, Vol. 58, No. 2, pp. 317-334.

[29] Markusen, J.R. (1983), "Factor Movements and Commodity Trade as Complements", Journal of International Economics, 19, pp. 341-356.

[30] Markusen, J.R. and Svensson, L.E.O (1985), "Trade in Goods and Factors with International Differences in Technology", International Economic Review, 26, pp. 175-192.

[31] Mussa, M. (1974), "Tariffs and the distribution of income: the importance of factor specificity, substitutability and intensity in the short and long run", Journal of Political Economy, 82, pp. 1191-1203.

[32] Neary, J. P. (1978), "Short-run capital specificity and the pure theory of international trade", Economic Journal, 88, pp. 458-510.

[33] Neary, J. P. (1995), "Factor Mobility and International Trade", Canadian Journal of Economics, 28, pp. 4-23.

[34] Paltseva, E. (2008), "Autocracy, Devolution and Growth", mimeo, University of Copenhagen.

[35] Persson, T. and Tabellini, G. (1994), "Is Inequality Harmful for Growth?," American Economic Review, Vol. 84 (3), pp. 600-621.

[36] Rigobon, R., and Rodrik, D. (2005), "Rule of Law, Democracy, Openness, and Income: Estimating the Interrelationships", Economics of Transition, Vol. 13, pp 533-564. 
[37] Rodrik, D. (1994), "Getting Interventions Right: How South Korea and Taiwan Grew Rich", NBER Working Paper No. 4964.

[38] Rodrik, D., Subramanian, A., and Trebbi, F. (2004), "Institutions Rule: The Primacy of Institutions over Geography and Integration in Economic Development", Journal of Economic Growth, Vol. 9, pp. 131-165.

[39] Samuelson, P.A. (1971), "Ohlin Was Right", Swedish Journal of Economics, 73, pp. 365-384.

[40] Segura-Cayuela, R. (2006), "Inefficient Policies, Inefficient Institutions and Trade", Documentos de Trabajo, No. 0633, Banco de España.

[41] Seim, A.L. and Parente, S.L. (2013), "Democracy as a Middle Ground: A Unified Theory of Development and Political Regimes", European Economic Review, 64, pp. 35-56.

[42] Shen, L. (2007), "When will a Dictator be Good?", Economic Theory Vol. 31, No. 2, pp. 343-366.

[43] Stefanadis, C. (2010), "Appropriation, Property Rights Institutions and International Trade", American Economic Journal: Economic Policy, Vol. 2, pp. 148-172.

[44] Tavares, S.C. (2007), "Do Rapid Political and Trade Liberalizations Increase Corruption?", European Journal of Political Economy, Vol. 23, No. 4, pp. 1053-1076.

[45] Treisman, D. (2000), "The Causes of Corruption: A Cross-National Study", Journal of Public Economics, Vol. 76, No. 3, pp. 399-457.

[46] Taylor, A.M. (1997), "Latifundia as Malefactor in Economic Development? Scale, Tenancy, and Agriculture on the Pampas, 1880-1914", Research in Economic History, Vol. 17, pp. 261-300.

[47] Wong, K. (1986), "Are International Trade and Factor Mobility Substitutes?" Journal of International Economics, 21, pp. 25-44. 


\section{Appendix A1: Utility Maximization}

Denote the bequests given in terms of capital and land by $B_{K t}$ and $B_{X t}$, respectively. The problem facing the capitalist household is then:

$$
\max _{C_{A t}, C_{M t}, B_{K t}} U\left(C_{A t}, C_{M t}, B_{K t}\right)=\left(C_{A t}^{\sigma} C_{M t}^{1-\sigma}\right)^{\mu} B_{K t}^{1-\mu}
$$

subject to

$$
P_{A t} C_{A t}+P_{M t} C_{M t}+P_{B t} B_{K t} \leq I_{K t}
$$

The optimal choices of the capitalist household are:

$$
\begin{aligned}
C_{A t} & =\mu \sigma \frac{I_{K t}}{P_{A t}}, \\
C_{M t} & =\mu(1-\sigma) I_{K t}, \\
B_{K t} & =(1-\mu) \frac{I_{K t}}{\xi} .
\end{aligned}
$$

The problem facing the landed household is:

$$
\max _{C_{A t}, C_{M t}, B_{X t}} U\left(C_{A t}, C_{M t}, B_{X t}\right)=\left(C_{A t}^{\sigma} C_{M t}^{1-\sigma}\right)^{\mu} B_{X t}^{1-\mu}
$$

subject to

$$
\begin{aligned}
P_{A t} C_{A t}+P_{M t} C_{M t} & \leq I_{X t} \\
B_{X t} & \leq x_{t}=1
\end{aligned}
$$

where $x_{t} \equiv X_{t} / N_{X t}$ denotes land holdings per landowner. Given $\mu=1$, the optimal choices of the landed household becomes:

$$
\begin{aligned}
C_{A t} & =\sigma \frac{I_{X t}}{P_{A t}} \\
C_{M t} & =(1-\sigma) I_{X t}, \\
B_{X t} & =1 .
\end{aligned}
$$

